DOI: https://doi.org/10.47405/mjssh.v5i5.403

\begin{tabular}{|c|c|}
\hline 4 & Malaysian Journal of Social Sciences and Humanities (MJSSH) \\
\hline $\begin{array}{l}\text { Malaysian Journal of } \\
\text { Social sciences and }\end{array}$ & Volume 5, Issue 5, May 2020 \\
\hline (MJ-SSH) & e-ISSN : 2504-8562 \\
\hline & $\begin{array}{l}\text { Journal home page: } \\
\text { www.msocialsciences.com }\end{array}$ \\
\hline
\end{tabular}

\title{
Consumer Behaviour in Green Purchasing: A Case Study in Petaling Jaya, Malaysia
}

\author{
Arissa Najmi Binti Khuzaimah¹, Fareez Ahmad Bin Taslim¹, Izza Farzana Binti Zabri', Khoo Jia Jia1, \\ Kughan Rao Ganamoorthi', Low En Ling1, Muhamad Akmal Bin Abu Samah', Isai Amutan Krishnan², \\ Kausalya Muthutamilselvan³, Vasudevan Naidu Kanan4, Selvajothi Ramalingam², Elanttamil \\ Maruthai ${ }^{2}$ \\ 1University of Malaya Centre for Continuing Education (UMCCed), University of Malaya (UM) \\ ${ }^{2}$ Faculty of Languages and Linguistics, University of Malaya (UM) \\ ${ }^{3}$ Lorong 2A/5 Taman Mutiara, Sg. Kob Karangan, Kulim, Kedah \\ ${ }^{4} \mathrm{O}$ 'Connor's Engineering Sdh. Bhd
}

Correspondence: Isai Amutan Krishnan (amuthan.isai@gmail.com)

\begin{abstract}
Malaysia faces several environmental issues, such as rising sea levels, water pollution, air pollution, climate changes, acid rain and soil erosion for the past few years. It is important to save the environment because by doing so, it will not only attract more tourists from foreign countries to come for vacation in Malaysia, but it also encourages manufacturers and consumers to support green product. Therefore, Malaysia should allocate the use of green products in daily life. Still, there are marketers who face problems in identifying and specifying factors that influence consumers to go green, which are; price, knowledge, eco-label and social influences. The environmental problem as well as lack of literature research about green products purchasing intention and minor companies that are involved in green production are also one of the problems that lead to the difficulties of this allocation. This research aims to identify the relationship between price, knowledge, eco-label and social influences towards consumer green purchase intention in Petaling Jaya. A theoretical model was developed and tested using quantitative survey approach. The data collection which are designed in five Likert-scale were gained from random 150 respondents in Petaling Jaya based on non-probability sampling. The results indicate that the most significant relationship between consumer green purchase intention is price. While knowledge, eco-label and social influences play important role too in influencing consumer purchasing intention towards green product although they do not give the most significant relationship. It is concluded that price sensitivity is found to be relative and consumers are willing to buy green product if the price of the green product is the same as the other non-environmental-friendly product.
\end{abstract}

Keywords: consumer behaviour, green purchasing, green products, environmental problem

\section{Introduction}

Malaysia faces several environmental issues such as rising sea levels, water pollution, air pollution, climate changes, acid rain and soil erosion. To save our environment is important to attract more manufacturer and consumers in Malaysia to support green products. The marketers have been facing problems to identify and specify the factors that influence consumers to go green. The factors have to be evaluated constantly (Muhammed Abdullah Sharaf \& Filzah Md Isa, 2017). Previous studies indicated that environmental problem, lack of literature research about the green products' purchasing 
intention and the existence of only small number of companies involved in green production in Malaysia to be some of the factors influencing customer's green purchase behaviour (Mokan, Bhoyar \& Lee, 2018). More than $97 \%$ of climate studies stated that the world is warming, mainly due to industrial pollution (Annie Qureshi, 2018). According to NUMBEO (2019), Kuala Lumpur, Malaysia is facing high air and water pollution. Variety of green products are found to be offered in North America and Europe, but not in Asia (Yam \& Tang, 1998; Sudiyanti, 2009). Therefore, the purpose of the present study is to identify the relationship between price, knowledge, eco-label and social influences towards consumer's green purchase intention.

\section{Literature Review}

Sathiswaran, Azlinda Shazneem Md Shuaib and Nurul Hasliana Hamsani (2014) conducted a study on The Role of Green Marketing Towards Purchase Intention among Malaysian Customers to investigate the relationship between green marketing strategies and customer's purchasing intention for green products. 200 questionnaires were collected from customers in Giant and Econ Save. That study was analysed by using the Structural Equation Model that comprised factor loading analysis, discriminant analysis and Goodness Model Fit. The findings found that there is a positive relationship between green marketing, strategies and customer's purchase intention towards green products.

A study called "An Investigation on the Additional Cost of Green Product: The Willingness to Pay of University Students" was conducted by Emre (2014) to investigate the willingness to pay among university students for additional cost of green products which revealed consequences for companies in terms of price adjustment. Quantitative approach was used where 432 out of 481 survey questionnaires were collected from students at Sakarya University. The finding proved that price sensitivity is found to be relative. It was also proven that the product itself is also important apart from the price.

The study of Manali Khaniwale (2015) examined consumer buying behaviour. Finding showed that factors influencing consumer's buying behaviour are culture, social, personal, and psychology. Qualitative method was used in that study where the instrument used was by observation method. Theoretical framework used in that study was Internal and External Factors Affecting Consumer Buying Behaviour.

A study of Customers' Intention to Use Green Products: The Impact of Green Brand Dimensions and Green Perceived Value was conducted by Aibek Doszhanov and Zainal Ariffin Ahmad (2015) with the objective to investigate the relationship of customer's intention to use green products towards green brand awareness, green brand image, green brand trusts, and green perceived value. Quantitative approach was usedwhere 384 out of 500 survey questionnaires were collected from customers of Carrefour, Giant and Tesco in Kuala Lumpur. The finding proved that there are significant positive relationship between green brand awareness, green brand trusts and green perceived value with customer's intention to use green products. However, brand image was not found to have significant relationship with customer's intention to use green products.

The study of Green Product Purchase Intention: Impact of Green Brands, Attitude, and Knowledge was conducted by Norazah Mohd Suki (2016) to assess the impact of green brand positioning, knowledge of green brand on green product purchase intention and attitude of consumer towards green brands. Apart from that, that research also studied the effect of green brand knowledge on consumer's attitude towards green brands. Moreover, that study examined the moderating effect of green brand knowledge on the relationship between green brand positioning and green product purchase intention. Quantitative approach was used, and 300 questionnaires were distributed. The purposive sampling technique was used, involving respondents who practice green lifestyle and had green product purchasing experience. The finding showed that green brand knowledge was found to be the most significant determinant of green product purchase intention and green brand knowledge also impacted consumer's attitude towards green brands. 
Ramya and Mohamed Ali (2016) examined Factors Affecting Consumer Buying Behaviour. That study was conducted in India. The consumer buying behaviour are affected by psychology, social, culture, economic and personal factors. Qualitative method was used, and the instrument for that study was experimental approach. Finding showed that consumer's environmental concern and products functional attributes emerged as two major determinants of consumer's green purchase behaviour.

Shamsi and Siddiqui (2017) conducted study on Green Product and Consumer Behaviour: An Analytical Study to understand the concept of green product and consumer behaviour. That study also investigated the relationship of green product usage and purchase intention with demographic variables. Structured questionnaire was used for primary data which were analysed using descriptive statistics and Pearson's chi-square test for independence. Descriptive design and conveniencesampling method was used that led to distribution and collection of 125 questionnaires. All the demographic variables such as age, gender and income were found to have no relationship with consumer's purchase decision of green products while educational qualification has.

A study of Impact of Green Marketing Mix on Purchase Intention which was conducted by Thoria Omer Mahmoud (2017) was done to investigate the influence of applying green marketing mix elements (product, pricing, distribution and promotion) in Sudan on purchase intention. A quantitative approach was used where 341 out of 417 survey questionnaires were collected from the postgraduate (MBA) students from all universities in Khartoum state that offer graduate level courses. The finding proved that the study provided better information as input to government policy makers, who are responsible for business development to encourage the manufacturing firm's use of green marketing to benefit key stakeholders' interests.

A study of Green Consumerism was conducted by Wiwik Handayani and Rendra Abdi Prayogo (2017) to analyse the influence of consumer's attitude of green product towards purchase intention. The dimensions of Attitude Towards Green Product variable are Ecoliteracy, Interpersonal influence and Value orientation. In that study, quantitative approach was used. In that research, purposive sampling technique with criteria was used. The questionnaires were distributed to 50 people at the age of at least of 21 years old who had experience in purchasing eco-friendly wall paint. The finding showed that all dimensions in variables of green products attitude show good validity. It can be concluded that consumer's attitude towards green product is able to increase consumer's purchase willingness.

Mokan, Bhoyar and Lee (2018) had conducted a study on The Intention of Green Products Purchasing among Malaysian Consumers: A Case Study of Batu Pahat, Johor. The objective of this study was to identify Malaysian consumers' intention towards purchasing the green product and to identify the relationship between knowledge, eco-label and social influence towards consumer purchase intention. Quantitative method was used to collect data through structured survey questionnaire in which 93 shoppers at Tesco Parit Raja, Batu Pahat Mall and Square One Mall had responded. The sampling technique that was applied was non-probability sampling. From the research, three factors that raise consumer's purchasing intention are knowledge, social influence and eco-label.

This research utilises the theoretical framework of Ajzen (1991) Theory of Planned Behaviour. Consumer's purchasing intention are influenced by price, knowledge, eco-labels and social influence. In most of the past studies, consumer purchasing intention were found to be influenced by culture, social, personal, and psychology. Majority of the past studies used qualitative methods, but the present study uses quantitative method where data collection was conducted through questionnaire. In terms of research method and data collection, this study is different from past studies which used observation and experimental approaches. 


\section{Definitions}

\section{Price}

Consumers are less likely to purchase green products if the products are more expensive (Blend \& Ravenswaay, 1999). However, there are also studies which indicated that there are more than 80 percent of Thai, Malaysian and Korean consumers who are willing to pay premium price to purchase environmental products (Dunlap \& Scarce, 1991).

\section{Knowledge}

As stated in previous study, person who are environmentally informed tend to engage in positive environmental behaviour (Hines, Hungerford \& Tomera, 1987). Another study also stated that there is a significant effect between knowledge and green purchasing intention (Mostafa, 2009).

\section{Eco-labels}

Consumers reform their buying behaviour and they consume products that they consider green (Ottman, 1993). To gain a special place in market, eco-labels can be attractive tools that are used to inform consumers on environmental significance of buying such products and services (Rashid, 2009).

\section{Social Influence}

Consumers buying decisions are always affected by family, friends, salesperson, and other person who share their experiences (Maram \& Kong, 2007). People who share the same way of thinking, desire and habits are likely to result in supporting eco-friendly behaviour (Zia-ur-Rehman \& Dost, 2013).

\section{Methodology}

\section{Conceptual Framework}

Ajzen (1991) Theory of Planned Behaviour which is shown in Figure 1 is used in this study. Purchasing intention will be influenced by price, knowledge, eco-labels and social influence.

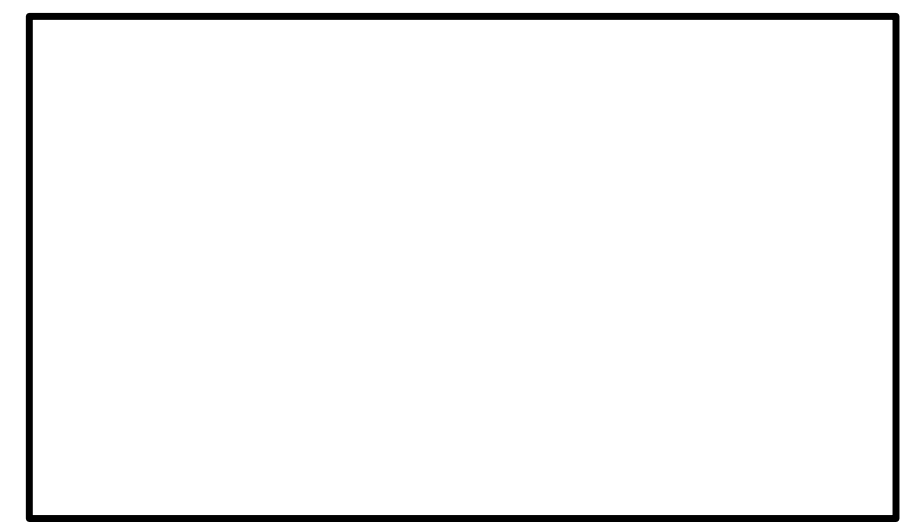

Figure 1. Ajzen (1991) Theory of Planned Behaviour

\section{Research Approach}

The questionnaires were distributed randomly in Petaling Jaya. Based on non-probability sampling, the sampling size is 157 people. The questions were merged from two previous studies; Section A from 
DOI: https://doi.org/10.47405/mjssh.v5i5.403

Tang (2014) and Section B and C from Muhammed Abdullah Sharaf and Filzah Md Isa (2017). Section A collects data on personal information which are gender, age, and race. Section B is based on the factors that affect consumer behaviour in purchasing green products. The factors included are price, knowledge, eco-labels and social influence. Section C collects information on consumer's purchase intention.

Table 1: Research Approach

\begin{tabular}{|c|c|c|}
\hline Setting & Sampling & Instrument \\
\hline Organization: & 157 Respondents based on & Questionnaire \\
\hline Green product manufacturing & Non-Probability Sampling & \\
\hline industries & Gender: & $\begin{array}{l}\text { Adopted from: } \\
\text { Muhammed Abdullah Sharaf }\end{array}$ \\
\hline $\begin{array}{l}\text { Nature of Business: } \\
\text { Manufacturing }\end{array}$ & Male and Female & $\begin{array}{l}\text { and Filzah Md Isa (2017) and } \\
\text { Tang (2014) }\end{array}$ \\
\hline \multirow[t]{3}{*}{$\begin{array}{l}\text { Location: } \\
\text { Petaling Jaya, Malaysia }\end{array}$} & $\begin{array}{l}\text { Age: } \\
\text { All }\end{array}$ & $\begin{array}{l}\text { Section A: } \\
\text { Demographic Information }\end{array}$ \\
\hline & $\begin{array}{l}\text { Race: } \\
\text { Mixed race } \\
\text { (Malay, Chinese, Indians and } \\
\text { others such as such as Dayak } \\
\text { people, Iban people, Bidayuh } \\
\text { and Sama-Bajau) }\end{array}$ & $\begin{array}{l}\text { Section B: } \\
\text { Factors Affecting Consumers' } \\
\text { Behaviour In Green } \\
\text { Purchasing }\end{array}$ \\
\hline & & $\begin{array}{l}\text { Section C: } \\
\text { Consumer Purchasing } \\
\text { Intention }\end{array}$ \\
\hline
\end{tabular}

\section{Data Collection and Data Analysis Procedures}

In step one, a written approval letter was collected from UMCced management as an approval for this survey to be conducted in Petaling Jaya.

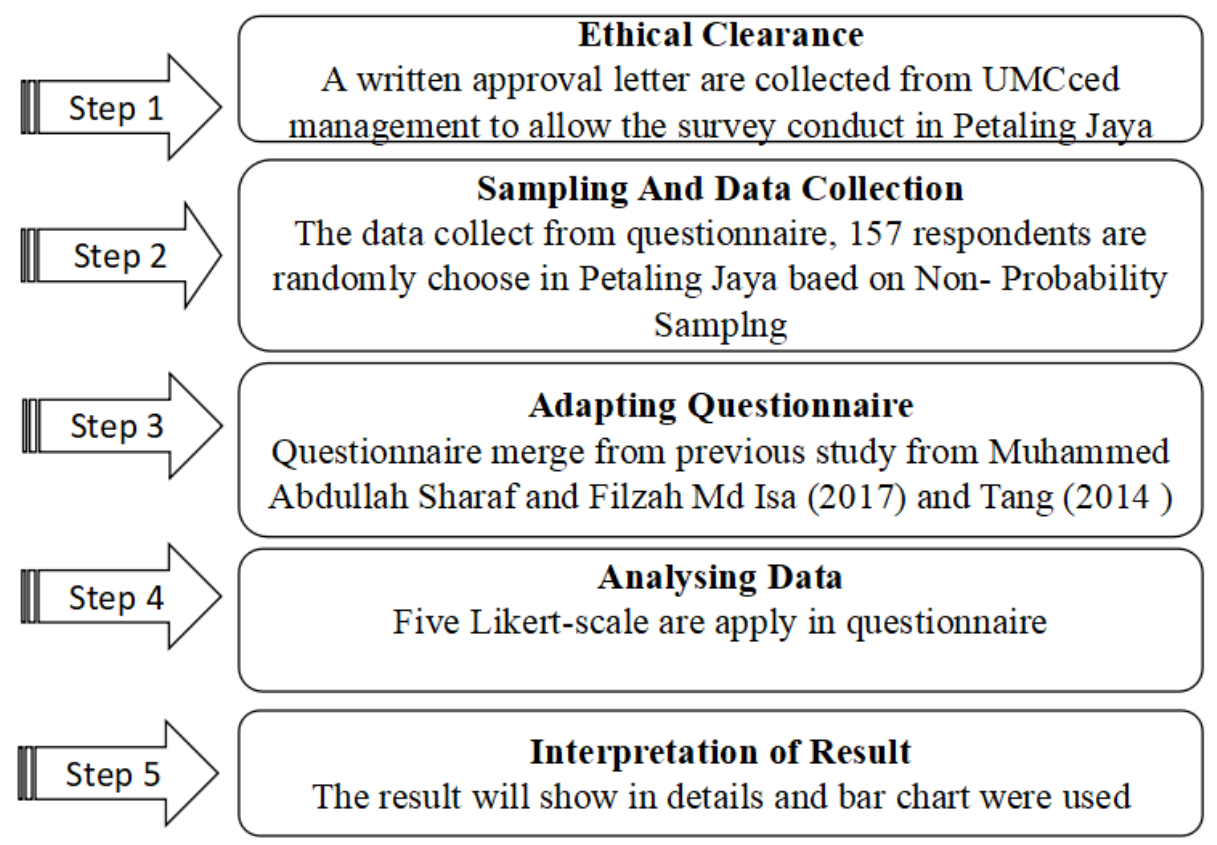

Figure 2. Data Collection and Analysis Procedures 
The respondents were asked whether they agree to answer the questionnaire. This is followed by step two, where data were collected by using questionnaire. The respondents were people in Petaling Jaya. Questionnaires were answered by 157 respondents who were chosen according to non-probability sampling. In step three, the list of questions in the questionnaire were adapted from the studies of Muhammed Abdullah Sharaf and Filzah Md Isa (2017) as well as Tang (2014). The questionnaires from both previous studies were originally in English version, but they were translated into Malay and Chinese versions for better understanding of respondents. Whereas in step four, the questionnaires were structured based on five-Likert scale, which indicated that $1=$ strongly disagree, $2=$ disagree, $3=$ neutral, $4=$ agree, and $5=$ strongly agree. Finally, in step five, the findings are discussed in the analysis section.

\section{Reliability and Validity}

All the independent and dependent variables were adapted from questionnaire by the study of Muhammed Abdullah Sharaf and Filzah Md Isa (2017). Cronbach's alpha of all the variables is 0.925 . Dependent variable has a Cronbach's alpha of 0.836, while for the independent variables, the value range between 0.70 and 0.88 . Result of Cronbach's alpha are as follow; Price (0.88), Knowledge (0.78), Eco-labels (0.70), Social Influence (0.73), and Purchasing Intention (0.87). The reliability of all the variables was good according to Cronbach's alpha values.

Table 2: Cronbach's Alpha Value

\begin{tabular}{lc}
\hline \multicolumn{1}{c}{ Item } & Cronbach's Alpha value \\
\hline Price & 0.88 \\
Knowledge & 0.78 \\
Eco-labels & 0.70 \\
Social Influence & 0.73 \\
Purchasing Intention & 0.87 \\
\hline
\end{tabular}

\section{Analysis and Discussion}

\section{Demographic Information}

The total number of respondents for this question were 157 people. Majority of participants are female $(55 \%)$ and other $45 \%$ of participants are male. For the age distribution, $44.59 \%$ of respondents are aged 20 years and below. While the respondents who are in the range of age $21-30$ years old are $31.21 \%$. Meanwhile, respondents aged $31-40$ years are $12.10 \%$ and, the range of $41-50$ years are $5.73 \%$. There are $6.73 \%$ of respondents aged 51 years and above. There are different race of respondents included in this survey. 57.32\% of those interviewed are Malays. While $33.76 \%$ of them are Chinese, $7.64 \%$ are Indians and there are $1.27 \%$ of other races such as Dayak, Iban, Bidayuh and Sama-Bajau. As for the monthly income, majority (60.53\%) of the respondents have monthly income below RM1999. While $16.58 \%$ of respondents have monthly income between RM2000 to RM2999. $14.65 \%$ of respondents have monthly income of more than RM4000. A minority of participants (8.28\%) have monthly income of RM3000 to RM3999.

Table 3: Demographic Information

\begin{tabular}{|c|c|c|}
\hline Demographic Information & Percentage & Respondents \\
\hline \multicolumn{3}{|l|}{ Gender } \\
\hline Male & $45.22 \%$ & 71 \\
\hline Female & $54.78 \%$ & 86 \\
\hline \multicolumn{3}{|l|}{ Age } \\
\hline 20 and below & $44.59 \%$ & 70 \\
\hline $21-30$ & $31.21 \%$ & 49 \\
\hline
\end{tabular}



DOI: https://doi.org/10.47405/mjssh.v5i5.403

\begin{tabular}{|c|c|c|}
\hline $31-40$ & $12.10 \%$ & 19 \\
\hline $41-50$ & $5.73 \%$ & 9 \\
\hline 51 and above & 6.37 & 10 \\
\hline \multicolumn{3}{|l|}{ Race } \\
\hline Malay & $57.32 \%$ & 90 \\
\hline Chinese & $33.76 \%$ & 53 \\
\hline Indian & $7.64 \%$ & 12 \\
\hline Other & $1.27 \%$ & 2 \\
\hline \multicolumn{3}{|l|}{ Monthly Income } \\
\hline Below RM1,999 & $60.51 \%$ & 95 \\
\hline RM2,000 - RM2,999 & $16.56 \%$ & 26 \\
\hline RM3,000 - RM3,999 & $8.28 \%$ & 13 \\
\hline RM4,000 and above & $14.65 \%$ & 23 \\
\hline
\end{tabular}

\section{Factor Influence Purchasing Intention}

\section{Price}

The most striking result that emerged from the data is that up to $80.25 \%$ of respondents are willing to purchase green product if the price are the same with other products in the same categories. This result come from $40.76 \%$ and $39.49 \%$ of the respondents which indicated agree and strongly agree. In this category, $17.20 \%$ of respondents indicated neutral in their answers. Only small numbers of respondents which consist of $0.64 \%$ and $1.91 \%$ answered strongly disagree and disagree. A possible explanation for this might be that people think that green products which have the same price with other products have the quality.

Table 4: Price

\begin{tabular}{cccccc}
\hline Question & $\begin{array}{c}\text { Strongly } \\
\text { Disagree }\end{array}$ & Disagree & Neutral & Agree & $\begin{array}{c}\text { Strongly } \\
\text { Agree }\end{array}$ \\
\hline $\mathbf{A}$ & 1 & 3 & 27 & 64 & 62 \\
& $0.64 \%$ & $1.91 \%$ & $17.20 \%$ & $40.76 \%$ & $39.49 \%$ \\
$\mathbf{B}$ & 2 & 5 & 43 & 71 & 36 \\
& $1.27 \%$ & $3.18 \%$ & $27.39 \%$ & $45.22 \%$ & $22.93 \%$ \\
$\mathbf{C}$ & 1 & 6 & 34 & 66 & 50 \\
& $0.64 \%$ & $3.82 \%$ & $21.66 \%$ & $42.04 \%$ & $31.85 \%$ \\
$\mathbf{D}$ & 4 & 7 & 40 & 71 & 35 \\
& $2.55 \%$ & $4.46 \%$ & $25.48 \%$ & $45.22 \%$ & $22.29 \%$ \\
$\mathbf{E}$ & 2 & 7 & 49 & 65 & 35 \\
& $0.64 \%$ & $4.46 \%$ & $31.21 \%$ & $41.30 \%$ & $22.15 \%$ \\
\hline
\end{tabular}

Next, for statement B which is "I'm willing to pay more for environmentally friendly products", $45.22 \%$ and $22.93 \%$ of respondents indicated that they are very likely to pay more for environmentally friendly products. However, $27.39 \%$ of them indicated neutral. Only $1.27 \%$ and $3.18 \%$ of respondents indicated strongly disagree and disagree which reflects that they are not willing to pay more for environmentally friendly products. It seems possible that these results are due to the fact that consumers are more concern about environment than the price. Thus, they are willing to pay more.

Furthermore, the majority of participants agreed and strongly agreed with the statement "If the price of green products is less expensive, I'm willing to change my lifestyle by purchasing green products". $42.04 \%$ of respondents indicated agree and $31.85 \%$ indicated strongly agree for the statement. While, $21.66 \%$ of the respondents indicated neutral. Only a small number of respondents which are $0.64 \%$ indicated strongly disagree and $3.82 \%$ indicated disagree, which reflect that they are not willing to 
change their lifestyle by purchasing green products even if the green products is less expensive. A possible explanation for this might be that consumers like to spend lesser to buy a product.

When asked about statement D, which is "I'm willing to pay more for groceries that are produced, processed and packaged in an environmentally friendly way", most of the respondents unanimously answered agree and strongly agree. $45.22 \%$ indicated agree and $22.29 \%$ indicated strongly agree. $25.48 \%$ of the respondents indicated neutral. Only a small number of respondents which consist of $2.25 \%$ strongly disagree and $4.46 \%$ disagree indicated that they are not willing to pay more for groceries that are produced, processed and packaged in an environmentally friendly way. It is difficult to explain this result, but it might be related to majority of respondents are concern about environment. Besides, over half of those survey reported that they agree with the statement "I would be willing to spend extra in order to buy fewer environmentally harmful products". $41.30 \%$ respondents agreed and $22.15 \%$ strongly agreed with the statement. $31.21 \%$ of respondents indicated neutral in their answers. A small number of respondents are not willing to spend extra in order to buy fewer environmentally harmful products. This consists of $0.64 \%$ strongly disagree and $4.43 \%$ disagree. This result may be explained by the fact that respondents are concern about environment.

\section{Knowledge}

The next section of the survey was knowledge. Majority (43.31\%) of the respondents indicated neutral for the statement "I know more about green products than the average person". Surprisingly, only a minority of respondents which are $38.22 \%$ and $14.65 \%$ of respondents agreed and strongly agreed that they know more about green products than the average person. Only minority of participants indicated disagree $(3.18 \%)$ and strongly disagree $(0.64 \%)$ to the statement. A possible explanation for these results may be the lack of adequate information of green product provided in Malaysia.

Table 5: Knowledge

\begin{tabular}{cccccc}
\hline Question & $\begin{array}{c}\text { Strongly } \\
\text { Disagree }\end{array}$ & Disagree & Neutral & Agree & Disagree \\
\hline $\mathbf{A}$ & 1 & 5 & 68 & 60 & 23 \\
& $0.64 \%$ & $3.18 \%$ & $43.31 \%$ & $38.22 \%$ & $24.65 \%$ \\
$\mathbf{B}$ & 1 & 5 & 53 & 75 & 23 \\
& $0.64 \%$ & $3.18 \%$ & $33.76 \%$ & $47.77 \%$ & $14.65 \%$ \\
$\mathbf{C}$ & 2 & 6 & 52 & 66 & 31 \\
& $1.27 \%$ & $3.82 \%$ & $33.12 \%$ & $42.04 \%$ & $19.75 \%$ \\
$\mathbf{D}$ & 1 & 16 & 62 & 59 & 19 \\
& $0.64 \%$ & $10.19 \%$ & $39.49 \%$ & $37.58 \%$ & $12.10 \%$ \\
$\mathbf{E}$ & 4 & 17 & 72 & 36 & 28 \\
& $2.55 \%$ & $10.83 \%$ & $45.86 \%$ & $22.93 \%$ & $17.83 \%$ \\
\hline
\end{tabular}

Next, the majority of the respondents, which are up to $47.77 \%$ felt that they know how to select products that reduce the amount of waste. There are $33.76 \%$ of the respondents indicated neutral. While $14.65 \%$ of respondents indicated strongly agree for the statement. A small amount of the participants indicated disagree $(3.18 \%)$ and strongly disagree $(0.64 \%)$ to the statement. These results are likely to be related to waste management policy that is implement in Malaysia.

In response to statement $\mathrm{C}$, most of those surveyed indicated that they understand the environmental phrases and symbols on product packages. There are $42.04 \%$ of the respondents indicated agree and $19.75 \%$ strongly agree to this statement. Whereas $33.12 \%$ of respondents indicated neutral. Whilst minority of the participants mentioned that they are unable to understand the environmental phrases and symbols on product packages.

Besides that, there are $39.49 \%$ of respondents who indicated neutral for the statement that they are very knowledgeable about green products. Only a minority of respondents which are $37.58 \%$ and $12.10 \%$ agreed and strongly agreed that they are very knowledgeable about green products. Up to 
$0.64 \%$ of respondents strongly disagreed and $10.19 \%$ of respondents disagreed for the statement. It seems possible that these results are due to lack of provision in Malaysian education system related to green product knowledge. Furthermore, there is less campaign in green product conducted in Malaysia.

Apart from that, majority of those who responded, which are $45.86 \%$ indicated neutral to the statement that they can give people advice about different brands of green products. Up to $22.93 \%$ of respondents indicated agree and $17.83 \%$ of respondents answered strongly agree that they can give people advice about different brands of green products. However, $2.55 \%$ and $10.83 \%$ of respondents strongly disagreed and disagreed for the statement. A possible explanation for this might be that people have less information of green product, so they are unable to give people advice.

\section{Eco-label}

When asked whether they consider what are printed on eco-labels to be accurate, $40.76 \%$ reported that they agree for the statement. Up to $39.49 \%$ of respondents indicated neutral for the statement. There are $13.38 \%$ of respondents who agreed and strongly agreed that they consider what are printed on ecolabels to be accurate. A minority of participants indicated disagree $(5.10 \%)$ and strongly disagree $(1.27 \%)$ for the statement. These results are likely to be related to consumer's awareness of the importance of eco-labels and the fact that the products' description in the eco-labels can promote whether the products have benefit and harmless the the environment.

Table 6: Eco-labels

\begin{tabular}{cccccc}
\hline Question & $\begin{array}{c}\text { Strongly } \\
\text { Disagree }\end{array}$ & Disagree & Neutral & Agree & $\begin{array}{c}\text { Strongly } \\
\text { Agree }\end{array}$ \\
\hline $\mathbf{A}$ & 2 & 8 & 62 & 64 & 21 \\
& $1.27 \%$ & $5.10 \%$ & $39.49 \%$ & $40.76 \%$ & $13.38 \%$ \\
$\mathbf{B}$ & 2 & 12 & 56 & 64 & 23 \\
& $1.27 \%$ & $7.64 \%$ & $35.67 \%$ & $40.76 \%$ & $14.65 \%$ \\
$\mathbf{C}$ & 2 & 5 & 53 & 76 & 21 \\
& $1.27 \%$ & $3.18 \%$ & $33.76 \%$ & $18.41 \%$ & $13.38 \%$ \\
$\mathbf{D}$ & 1 & 5 & 51 & 63 & 37 \\
& $0.64 \%$ & $3.18 \%$ & $33.76 \%$ & $40.13 \%$ & $23.57 \%$ \\
$\mathbf{E}$ & 1 & 3 & 32 & 74 & 47 \\
& $0.64 \%$ & $1.91 \%$ & $32.48 \%$ & $47.13 \%$ & $29.94 \%$ \\
\hline
\end{tabular}

Next, respondents were asked to indicate whether they can easily understand the information on ecolabels. $40.76 \%$ and $14.65 \%$ of respondents agreed and strongly agreed that they can easily understand the information on eco-labels. There are $35.67 \%$ of respondents who indicated neutral for this statement. A small number of the participants indicated disagree (7.64\%) and strongly disagree $(1.27 \%)$ for the statement. It seems possible that these results are due to the fact that eco-labels provide straight forward descriptions and they are easy to understand by consumers.

Besides, the majority of participants agreed with the statement that they are satisfied with the information available on the eco-label of the green products. This result consists of $18.41 \%$ of respondents who agreed and $13.38 \%$ strongly agreed. While $33.76 \%$ of the respondents indicated neutral for this statement. There are only a small number of respondents who indicated that they disagreed $(3.18 \%)$ and strongly disagreed $(1.27 \%)$ of the statement. This result may be explained by the fact that eco-labels in Malaysia are approved by certain trustable institutions.

Almost two-thirds of the participants said that they agree and strongly agree that they believe in the information on green products. The results consist of $40.13 \%$ of respondents who agreed and $23.57 \%$ strongly agreed. There are $32.48 \%$ of respondents responded neutral for this statement. A minority of participants indicated disagree $(3.18 \%)$ and strongly disagree $(0.64 \%)$ for the statement. This result 
can also be explained with the fact that eco-labels in Malaysia are approved by certain trustable institutions.

In response to whether they appreciate the package and design of green product or not, most of those surveyed indicated that they agree and strongly agree to the statement. There are $47.13 \%$ of respondents who agreed and $29.94 \%$ of respondents strongly agreed. While, $32.48 \%$ of respondents responded neutral in this statement. Whilst a minority mentioned that they do not appreciate the package and design of green product which include $1.91 \%$ of respondents indicated that they disagree and $0.64 \%$ strongly disagree. These results can be explained by the fact that the outlook of the products is important for consumer in making their purchase decision.

\section{Social Influence}

Over half of those who answered this question reported that they agree $(40.76 \%)$ and strongly agree $(20.38 \%)$ that they are encouraged to buy green products by someone important to them. However, $33.12 \%$ of the respondents indicated neutral for the statement. A small number of the participants which consist of $3.82 \%$ and $1.91 \%$ indicated strongly disagree and disagree that they are encouraged to buy green products when someone important to them ask to.

Table 7: Social Influence

\begin{tabular}{cccccc}
\hline Question & $\begin{array}{c}\text { Strongly } \\
\text { Agree }\end{array}$ & Disagree & Neutral & Agree & $\begin{array}{c}\text { Strongly } \\
\text { Agree }\end{array}$ \\
\hline $\mathbf{A}$ & 6 & 3 & 52 & 64 & 32 \\
& $3.82 \%$ & $1.91 \%$ & $33.12 \%$ & $40.76 \%$ & $20.38 \%$ \\
$\mathbf{B}$ & 2 & 11 & 57 & 58 & 29 \\
& $1.27 \%$ & $7.01 \%$ & $36.31 \%$ & $36.94 \%$ & $18.47 \%$ \\
$\mathbf{C}$ & 2 & 8 & 52 & 63 & 30 \\
& $1.27 \%$ & $5.10 \%$ & $33.12 \%$ & $41.40 \%$ & $19.11 \%$ \\
$\mathbf{D}$ & 2 & 15 & 60 & 52 & 28 \\
& $1.27 \%$ & $9.55 \%$ & $38.22 \%$ & $33.12 \%$ & $17.83 \%$ \\
$\mathbf{E}$ & 4 & 14 & 56 & 58 & 25 \\
& $2.55 \%$ & 8.92 & $35.67 \%$ & $36.94 \%$ & $15.92 \%$ \\
\hline
\end{tabular}

Besides, the majority of participants which consist up to $36.94 \%$ agreed with the statement that their friends think that they should purchase green products. While, $36.31 \%$ of respondents are neutral. Besides, $18.47 \%$ of the respondents strongly agreed for the statement. Whilst a minority of them mentioned that they disagree (7.01\%) and strongly disagree $(1.27 \%)$.

Over half of those surveyed reported that they agree and strongly agree for the statement "My family thinks that I should purchase green products". This result included $41.40 \%$ of respondents who agreed and $19.11 \%$ strongly agreed. While $33.12 \%$ of respondents responded neutral. A minority of participants indicated that they disagree $(5.10 \%)$ and strongly disagree $(1.27 \%)$.

Furthermore, when the participants were asked whether they learn a lot about environmental friendly products from friends, the majority (38.22\%) indicated neutral. There are $33.12 \%$ of respondents who agreed and $14.65 \%$ strongly agreed for the statement. Whilst a minority mentioned that they do not agree with the statement which include $9.55 \%$ of respondents indicated for disagree and $1.27 \%$ for strongly disagree.

Besides, the majority of participants agreed with the statement that they always share information regarding environmental-friendly products with family and friends. There are $36.94 \%$ of respondents who agreed and $15.92 \%$ of respondents strongly agreed. Up to $35.67 \%$ of respondents indicated neutral for this statement. A small number of those who answered the survey which included $8.92 \%$ and $2.55 \%$ of respondents disagreed and strongly disagreed for the statement. 


\section{Purchasing Intention}

When the participants were asked about their willingness to purchase green product, the majority commented that they agreed and strongly agreed with the statement. There are $45.22 \%$ and $28.66 \%$ of the respondents who are willing and strongly willing to buy green products. Meanwhile, $22.29 \%$ of the respondents indicated neutral for this statement. A small number of those surveyed which included $2.55 \%$ and $1.27 \%$ are found to disagree and strongly disagree for the statement.

Besides, over half of those surveyed reported that they agreed and strongly agreed that they are likely to buy green products in the future. This included $42.68 \%$ of respondents who agreed, and $27.39 \%$ respondents strongly agreed. However, $24.84 \%$ of the respondents indicated neutral for this statement. Whilst a minority indicated that they disagree (4.46\%) and strongly disagree $(0.64 \%)$.

Next, the majority of participants agreed with the statement that they are willing to continuously buy green products. There are $41.40 \%$ of the respondents who agreed while there are $27.39 \%$ who strongly agreed for the statement. Meanwhile, $23.57 \%$ of respondents responded neutral. A small number of those surveyed indicated that they disagree $(7.01 \%)$ and strongly disagree $(0.64 \%)$.

When asked whether they are willing and strongly willing to pay more when purchasing green products, $30.57 \%$ respondents indicated neutral for the statement. Up to $40.13 \%$ of respondents agreed and $24.84 \%$ strongly agreed with the statement. A small number of respondents indicated disagree $(3.82 \%)$ and strongly disagree $(0.64 \%)$ for the statement.

Table 8: Purchasing Intention

\begin{tabular}{cccccc}
\hline Question & $\begin{array}{c}\text { Strongly } \\
\text { Disagree }\end{array}$ & Disagree & Neutral & Agree & $\begin{array}{c}\text { Strongly } \\
\text { Agree }\end{array}$ \\
\hline $\mathbf{A}$ & 2 & 4 & 35 & 71 & 45 \\
& $1.27 \%$ & $2.55 \%$ & $22.29 \%$ & $45.22 \%$ & $28.66 \%$ \\
B & 1 & 7 & 39 & 67 & 43 \\
& $0.64 \%$ & $4.46 \%$ & $24.84 \%$ & $42.68 \%$ & $27.39 \%$ \\
C & 1 & 11 & 37 & 65 & 43 \\
& $0.64 \%$ & $7.01 \%$ & $23.57 \%$ & $41.40 \%$ & $27.39 \%$ \\
D & 1 & 6 & 48 & 63 & 39 \\
& $0.64 \%$ & $3.82 \%$ & $30.57 \%$ & $40.13 \%$ & $24.84 \%$ \\
\hline
\end{tabular}

Overall, these results indicated that all of the factors which are price, knowledge, eco-labels and social influence will affect consumer's purchasing intention towards green product. While, price has the most significant relationship between consumer's purchasing intention of green products.

It can be clearly shown that there is significant relationship between consumer behaviour in green purchasing and the four factors which are price, eco-label, social influence and knowledge. The results of this study illustrate that price is most significant factor which affects green purchasing behaviour.

For Price, majority of respondents indicated that they are willing to choose green product if the price are the same with other products in the same categories. Participants agreed that they are willing to pay more to purchase green product and also like to spend less for green product. Comparing the results, it can be seen that there is highest percentage $(80.25 \%)$ of respondents who are willing to purchase green products if the price are the same.

For Knowledge, majority of the respondents indicated neutral in the question that they are very knowledgeable and know more about green product than others, as well as able to give people advice about green products. Meanwhile, the majority of participants agreed that they know how to select products that reduce the amount of waste and understand the environmental phrases and symbols on product packages. 
For eco-labels, majority of the respondents agreed that they consider what are printed on eco-labels to be accurate, the information on eco-labels can be easily understood, and they are satisfied with the information available on the eco-labels of the green products. They also believe in the information on green products. Up to $77.07 \%$ of respondents appreciated the package/design of green products.

For Social Influence, majority of the respondents are encouraged to purchase green products by people who are important to them. Comparing the two results, it can be seen that most of the respondents are encouraged by families rather than friends. Majority of respondents indicated neutral for the statement "I learn a lot about environmental-friendly products from my friends", while, most of the respondents will share information regarding environmental-friendly products with their friends and family.

For Purchasing Intention, majority of the respondents are willing to purchase green product and willing to purchase in the future. Majority of the respondents are willing to buy green product continuously and willing to pay more.

\section{Implication and Limitations of the study}

The results of this research show that price, knowledge, eco-labels and social influence will affect consumer's purchasing intention. Moreover, price is proven to be the most significant factor that influences consumer's purchasing intention. However, in other studies, the results showed that only price and social influence have positive relationships between consumer's purchasing intention, but knowledge and eco-labels have negative relationships.

In this research, we have found some limitations while conducting this study. The first limitation is geographical bias. This study is conducted only in Petaling Jaya area. If the research is conducted in different area, the result may be different. There are more areas that have not been discovered yet. This limitation remains unsolved as we can only conduct survey in Pertaling Jaya area. Second limitation of this study is that the data of this study were only collected in one point of time, which is from January to April 2019. Consumer behaviour may change according to time. This research has been conducted in short time, whereby it only represents consumer behaviour at one point of time. This limitation remains unsolved as we did not expand the time to collect data.

\section{Further Research}

As for the factors that influence consumer behaviour in green purchasing, there are still more tasks to be carried out. This study shows 4 factors which are price, knowledge, eco-labels and social influence which could affect consumer behaviour in green purchasing. As a recommendation, future researchers are suggested to include more independent variables. Other than the four variables used in this research, there are still many factors that actually affect consumer's behaviour in green purchasing. Hence, future researchers can include other factors of consumer's purchasing intention. This may provide contribution to marketers and manufacturers to increase their sales while helping the country to have less environmental issues.

Furthermore, the researchers can expand the area of research. This is because environmental issue does not only occurr in Malaysia, it also happens in other countries. Moreover, marketers and manufacturers in other area apart from Petaling Jaya also have problems in identifing and specifying the factors that influence consumers to go green. The result might be different if the research is carried out in other areas, which might be more useful for the manufacturers and marketers in that particular area.

Besides that, future researchers are also suggested to increase the sample size while conducting survey research. This is because, the more numbers of respondents, the more accurate results will be acquired. Thus, the future research study will be more reliable and valuable. There are some limitations in this study. First limitation is geographical bias. This study is conducted only in Petaling Jaya area, hence 
the results do not represent the view of all consumers in Malaysia. Moreover, data of this study were only collected at one point of time, which is from January to April 2019. Consumer behaviour may change according to time. In short, this research only represents consumer behaviour at one point of time.

This research shows the result of factors that influence consumer's purchasing intention in terms of price, knowledge, eco-labels and social influence. Besides that, it also shows demographic information and consumer's purchasing intention. The researchers also discuss about the implication and limitation of this study. Lastly, the researchers have provided the recommendation to the future researchers to gain more information in the related research study.

\section{References}

Adofo, S. (2013). Challenges And Coping Strategies Of Student Nursing Mothers In Tertiary Institutions In The Greater Accra Region Of Ghana (M.Phil). University of Ghana.

Aibek, D., \& Zainal, A. A. (2015). Customers' intention to use green products: the impact of green brand dimensions and green perceived value. SHS Web of Conferences, 18, 2-4.

Anvar, M., \& Venter, M. (2014). Attitudes and purchase behaviour of green products among generation y consumers in south africa. Mediterranean Journal of Social Sciences, 5(21), 183193.

Blend, J. R., \& van Ravenswaay, E. O. (1999). Measuring consumer demand for ecolabel apples. American Journal of Agriculture Economics, 81(5), 1072-1077.

D'ames, A. (2014). The impact of green product on the customer purchasing behaviour: An analytical study on a sample of the technological companies at amman. Global Journal of Management and Business Research: E Marketing, 14(6), 27-31.

Dunlap, R. E., \& Scarce, R. (1991). Environmental problems and protections. public opinion quarterly, $55,651-672$.

Emre, Y. (2014). An investigation on the additional cost of green products: the willingness to pay of university students. Journal of Sustainable Development Studies, 7(1), 132-146.

Hameed, O. A., Hasbullah, A., \& Norani, N. (2015). An empirical study on the influence of sustainable environmental manufacturing practice on firm performance. Journal of Sustainability Science and Management, 10(2), 42-51.

Hayatul, S. S., \& Nor Azila, M. N. (2018). Moderating effect of self-efficacy on the relationship between consumer attitude and willingness to consume healthy food. Journal of Sustainability Science and Management, 4, 33-50.

Hines, J. M., Hungerford, H. R., \& Tomera, A. N. (1987). Analysis and synthesis of research on responsible environmental behaviour: A meta-analysis. The Journal of Environmental Education, 18(2), 1-8.

K. V. Mokan., Lee, T. C., \& M. R. Bhoyar. (2018). The intention of green products purchasing among Malaysian consumers: A case study of Batu Pahat, Johor. Indian Journal of Public Health Research and Development, 9(10), 997-999.

Mohammad, S., Abdullah, O., \& Mohd, S. A. H. (2015). Green Marketing: A Marketing Mix Point of View. International Journal of Business and Technopreneurship, 5(1), 88-94.

Mohd Nazdrol, W. M. N., Che Rusli, M. S., \& Nabila, A. N. (2016). The influencing factor of purchasing ecological products: let's think green. Journal of Technology Management and Business, 3(2), 36-43.

Mohd, S. S., \& Z S Siddiqui. (2017). Green product and consumer behaviour: An analytical study. Pertanika Journal of Social Science and Humanities, 25(4), 1547-1552.

Mostafa, M. M. (2009). Shades of green: A psychographic segmentation of the green consumer in Kuwait using self-organizing maps. Expert Systems with Applications, 36(8), 11030-11038.

Muhammed Abdullah Sharaf., \& Filzah Md Isa. (2017). Factors influencing students' intention to purchase green products: A case study in Universiti Utara Malaysia. Pertanika Journal of Social Science and Humanities, 25(2), 240-245. 
Nguyen, V. K., Vu, A. D., \& Nguyen, Q. N. (2016). R\&D investment of Japanese multinational corporations in Vietnam through green supply chain: the case of Ajinomoto. Journal of Sustainability Science and Management, 11(1), 43-52.

Norazah, M. S. (2013). Green awareness effects on consumers' purchasing decision: some insights from Malaysia. International Journal of Asia Pacific Studies, 9(2), 52-56.

Norazah, M. S. (2013). Green products purchases: Structural relationships of consumers' perception of eco-label, eco-brand and environmental advertisement. Journal of Sustainability Science and Management, 8(1), 1-10.

Norazah, M. S. (2016). Green product purchase intention: Impact of green brands, attitude, and knowledge. British Food Journal, 118(12), 2895-2905.

Ottman, J. A. (1993). Green marketing: challenges and opportunities. Chicago: NTC Business Books. Pollution in Kuala Lumpur, Malaysia. Retrieved May 18, 2019, from https://www.numbeo.com/pollution/in/Kuala-Lumpur

Rahab, T., Nugroho, S. S., Dharmmesta, B. S., \& Widyaningsih, Y. A. (2016). Green product purchasing phenomenon: exploring he gaps of theoretical, methodological and empirical. MIMBAR, 32(2), 372-381.

Ramya, N., \& SA Mohamed Ali. (2016). Factors affecting consumer buying behavior. International Journal of Applied Research, 2(10), 76-80.

Rashid, N. R. N. A. (2009). Awareness of Eco-label in Malaysia's green marketing initiative. International Journal of Business and Management, 4(8),132-135.

Tan, B. C., \& Lau, T. C. (2011). Green purchase behavior: examining the influence of green environmental attitude, perceived consumer effectiveness and specific green purchase attitude. Australian Journal of Basic and Applied Sciences, 5(8), 559-567.

Tan, C. L., Goh, Y. N., \& Chan, H. S. (2015). A model linking institutional factors and green initiatives: A study among the private higher education institutions. Journal of Sustainability Science and Management, 10(2), 52-64.

Tang, S. M. (2014). Factors That Influence Green Purchase Behaviour of Malaysian Consumers. 1243.

Thoria, O. M. (2017). Impact of green marketing mix on purchase intention. International Journal of Advanced and Applied Sciences, 5(2), 127-135.

Wiwik, H., \& Rendra, A. P. (2017). Green consumerism: An eco-friendly behaviour form through the green product consumption and green marketing. SINERGI, 7(2), 26-28.

Rehman, Z.U., \& Dost, M. K. (2013). Conceptualizing green purchase intention in emerging markets: An empirical analysis on Pakistan. The West East Institute, 101-106.

\section{Authors' Details}

1. Ms. Khoo Jia Jia is currently doing her Diploma in Accounting at University of Malaya Centre for Continuing Education (UMCCed), and her area of interest are accounting and business.

Email address : capricornjia9922@gmail.com

HP : : $\quad: 60136097701$

Address : Wisma R\&D, University of Malaya, Jalan Pantai Baharu, Taman Bukit Pantai, 59100 Kuala Lumpur, Wilayah Persekutuan Kuala Lumpur

2. Ms. Low En Ling is currently pursuing her Diploma in Accounting in University of Malaya Centre for Continuing Education (UMCCed) and her interests are in accounting, management and taxation.

Email address : lowenling98@gmail.com

HP : : $\quad$ :6016-3269339

Address : Wisma R\&D, University of Malaya, Jalan Pantai Baharu, Taman Bukit Pantai, 59100 Kuala Lumpur, Wilayah Persekutuan Kuala Lumpur 
Malaysian Journal of Social Sciences and Humanities (MJSSH), Volume 5, Issue 5, (page 44 - 59), 2020

DOI: https://doi.org/10.47405/mjssh.v5i5.403

3. Ms. Arissa Najmi Binti Khuzaimah is currently doing her Diploma in Accounting at University of Malaya Centre for Continuing Education (UMCCed) and her interests are in business, management and accounting.

Email address : arissa1806@gmail.com

HP : : $\quad$ : $\quad$ :019-2177553

Address : Wisma R\&D, University of Malaya, Jalan Pantai Baharu, Taman Bukit Pantai, 59100 Kuala Lumpur, Wilayah Persekutuan Kuala Lumpur

4. Ms. Izza Farzana Binti Zabri is currently pursuing her Diploma in Accounting in University of Malaya Centre for Continuing Education (UMCCed), and her interests are in research, accounting and taxation.

Email address : izzazana@gmail.com

HP : $\quad:$ :6017-8822001

Address : Wisma R\&D, University of Malaya, Jalan Pantai Baharu, Taman Bukit Pantai, 59100 Kuala Lumpur, Wilayah Persekutuan Kuala Lumpur

5. Kughan Rao Ganamoorthi is currently pursuing his Diploma in Accounting in University of Malaya Centre for Continuing Education (UMCCed), and his interests are in research, accounting, auditing and taxation.

Email address : kughanraoganamoorthi@gmail.com

HP : : $\quad$ :6019-6150569

Address : Wisma R\&D, University of Malaya, Jalan Pantai Baharu, Taman Bukit Pantai, 59100 Kuala Lumpur, Wilayah Persekutuan Kuala Lumpur

6. Mr. Fareez Ahmad Bin Taslim is currently pursuing his Diploma in Accounting in University of Malaya Centre for Continuing Education (UMCCed), and his interests are in research, accounting, auditing and taxation.

Email address : fareezahmadt@gmail.com

HP : : $\quad: 6013-3794830$

Address : Wisma R\&D, University of Malaya, Jalan Pantai Baharu, Taman Bukit Pantai, 59100 Kuala Lumpur, Wilayah Persekutuan Kuala Lumpur

7. Mr. Muhamad Akmal bin Abu Samah is currently pursuing his Diploma in Accounting in University Malaya Centre for Continuing Education (UMCCed) and his interest are in research, accounting, auditing and taxation.

Email address : akmalabusamah@gmail.com

HP : : $\quad$ :6013-7933544

Address : Wisma R\&D, University of Malaya, Jalan Pantai Baharu, Taman Bukit Pantai, 59100 Kuala Lumpur, Wilayah Persekutuan Kuala Lumpur

8. Mr. Isai Amutan Krishnan is currently doing his $\mathrm{PhD}$ at the Faculty of Languages and Linguistics, University of Malaya (UM), and his area of interests are in human resource development \& management, ELT, and performing arts. He is also a freelance consultant locally and abroad.

Email address : amuthan.isai@gmail.com,

HP $\quad:+60123845100$

Address $\quad$ : Faculty of Languages and Linguistics, University of Malaya, 50603 Kuala Lumpur 
DOI: https://doi.org/10.47405/mjssh.v5i5.403

9. Ms. Kausalya Muthutamilselvan is a STPM leaver. She has been waiting for her a university enrolment to pursue her territory education in Law. Her experience in research projects during her school embarks her to explore further in multi discipline research. Presently, her passion into English language teaching, linguistics field as well as performing arts.

Email address : Legalya0808@gmail.com,

HP : : +60166905178

Address : No. 3413, Lorong 2A/ 5Taman Mutiara, Sg. Kob Karangan, 09700, Kulim, Kedah

10. Mr. Vasudevan Naidu Kanan is currently a Project Manager in the Business Communication Department of O'Connor's Engineering Sdn. Bhd, Kuala Lumpur. He did his Masters in Global Business from SEGI University Kota Damansara. He used to work in CIMB Group from the department of Client Management. His research interest is in social sciences, business and information technology.

Email address : evanleo05@gmail.com

HP : : +60129790535

Address : O'Connor's Engineering Sdn. Bhd. Bagunan O'Connor No.13 Jlaan 223, 46100 Petaling Jaya, Selangor.

11. Dr. Selvajothi Ramalingam (PhD) is currently a senior Lecturer in the Department of Malaysian Languages and Applied Linguistics, Faculty of Languages \& Linguistics, University Malaya, Kuala Lumpur. Before the appointment, he was the Assistant Director of Tamil and International languages subjects for the Selangor State Education Department. He was a secondary school Tamil teacher with 20 years of experience. His research interests are in sociolinguistics, language shift and maintenance, language and identity and applied linguistics.

Email address : selvajothi@um.edu.my

HP : : $\quad$ :60192267579

Address : Faculty of Languages and Linguistics, Department of Malaysian Languages and Applied Linguistics, University Malaya, 50603 Kuala Lumpur

12. Mr. Elanttamil Maruthai is a lecturer at the Department of Malaysian Languages and Applied Linguistics, Faculty of Languages \& Linguistics, University of Malaya. His area of expertise is in Applied Linguistics (Discourse and genre studies and Corpus Linguistics).

Email address : elanttamil@um.edu.my

HP : +60123143910

Address : Faculty of Languages and Linguistics, Department of Malaysian Languages and Applied Linguistics, University of Malaya, 50603 Kuala Lumpur 